\title{
THE MARXIAN PROFIT RATE: A SUGGESTED REFORMULATION
}

\author{
MARX'DA KAR HADDİ: BİR YENIDEN YORUMLAMA ÖNERİİ
}

Reşat KAYALI*

Özet

Bu makalenin amacı Marx’n kar haddi kavramını iki mallı bir teorik model bağlamında yeniden yorumlayarak Ricardo-Sraffa geleneğindeki kar haddi kavramıyla karşılaştırılabilir bir tanıma kavuşturmaktır. $\mathrm{Bu}$ yeniden yorumlama çabasının sonuçları Marx’’n değer ve bölüşüm teorisi ile kapitalist gelişim teorisi bağlamında irdelenmektedir. İlk olarak emek - değer teorisi bu iki mallı model bağlamında kanıtlanarak iki mallı modeldeki fiyat oranının birim emek katsayılarının oranına eşit olduğu gösterilmektedir. Daha sonra kar kavramı kaynak tahsisinde etkinliğin sağlanmasındaki rolü ve kapitalist sınıf tarafından temellük edilen bir gelir kategorisi olması açısından irdelenmektedir. Bunu takiben önerilen yeniden yorumlamanın ıșı̆ğında Marx’ın kapitalist gelişim teorisindeki azalan kar haddi yasasıyla artan yoksullaşma yasasının hangi şartlar altında eş anlı olarak geçerli olabileceği sorunu irdelenmektedir. Bu yeniden yorumlama çabasının sonucunda Marx’n değer ve bölüşüm teorisi ile kapitalist gelişim teorisindeki bazı önemli sonuçların geçerli olabilmesi için gerekli şartların sayısının daha da arttı̆̆ı anlaşılmaktadır.

Anahtar Kelimeler: Marxist İktisat, İktisadi Düşünce Tarihi, Ekonomi Politik

JEL Sınıflandırması: B14, B51

\begin{abstract}
The paper attempts to reformulate Marx's definition of the profit rate in a two-good framework so that it can be compared with the definition of the profit rate in the Ricardo-Sraffa tradition. The implications of this reformulation are investigated with regard to Marx's theory of value and distribution and his theory of capitalist development. Specifically, the labor theory of value is proven where the price ratio in a two-good framework is shown to be equal to the ratio of unit labor requirements. Then, profits are discussed in terms of allocative efficiency and in the context of their appropriation by the capitalist class. Subsequently, there is a discussion of the compatibility of the law of the falling rate of profit and the law of increasing misery. The conclusion of the paper is that the suggested reformulation of the profit rate increases the number of necessary conditions that must be satisfied for some key results to hold in Marx's theory of value and distribution and his theory of capitalist development.
\end{abstract}

Prof. Dr. Reşat Kayalı, Özyegin Üniversitesi, Çekmeköy, İstanbul, resat.kayali@ozyegin.edu.tr

Orcid Id: 0000-0001-7675-6697 
Keywords: Marxian Economics, History of Economic Thought, Political Economy

JEL Classification: B14, B51

\section{The Reformulated Profit Rate and The Labor Theory of Value}

In his analysis of the capitalist economy, even though Marx insisted on relegating prices and profits to the domain of 'appearances' as opposed to values and surplus values which, according to him, rested in the domain of 'reality', his definition of the profit rate as the ratio of surplus value to the sum of constant and variable capital remains curiously in the domain of reality. The definition of the profit rate in the Ricardo-Sraffa tradition, however, is simply the ratio of money profits to the value of capital invested. We will introduce a number of assumptions while preserving Marxian concepts so that Marx's profit rate is consistently defined in the domain of appearances as well. Our objective is to see if any of the key results in Marx's theory of value and distribution and his theory of capitalist development are affected by our reformulation.

We will begin by introducing a key concept in the Marxian theory of value and distribution, namely, the labor embodied theory of value (hereafter LTV), to which Marx attributed a critical role in analyzing the capitalist economy.

Statement of the LTV:

Prices of commodities are proportional to the quantities of labor directly and indirectly embodied in them.

Before Marx, Adam Smith argued that the LTV would hold exactly in a primitive society where labor was the only scarce factor of production. Think of this as a society of hunters where capital costs are negligible and land is freely available. ${ }^{1}$

In a modern economy, however, the LTV will not hold generally because capital and land are also scarce and a positive price must be paid for both of them. To see why this is so, consider a very simple production process. Two wine producers, A and B borrow money from the bank at the going rate of interest and go into wine production. A needs five hours of labor and B needs three hours of labor to produce a bottle of wine because they are producing different kinds of wine. The current wage rate is the same for both of them, and both kinds of wine mature over a period of two years. The price equations for the two kinds of wine are as follows:

1 The standard reference is Adam Smith's beaver/deer parable: "In that early and rude state of society, which precedes both the accumulation of stock and the appropriation of land, the proportion between the quantities of labour necessary for acquiring different objects seems to be the only circumstance which can afford any rule for exchanging them for one another. If among a nation of hunters, for example, it usually costs twice the labour to kill a beaver which it does to kill a deer, one beaver should naturally exchange for or be worth two deer. It is natural that what is usually the produce of two days or two hours labour, should be worth double of what is usually the produce of one day's or one hour's labor." Smith (1937) [1776], p. 47. 
$\mathrm{P}_{\mathrm{A}}=5 \mathrm{w}(1+\mathrm{r})^{2}$

$\mathrm{P}_{\mathrm{B}}=3 \mathrm{w}(1+\mathrm{r})^{2}$

Note that these are long-run equilibrium prices which just cover costs. Note further that wine production is unique in the sense that it requires a substantial amount of labor at the beginning of the production period and a much smaller amount at the end which is ignored in this example. This means that all labor costs must be paid at the beginning of the production period. Moreover, the price of wine must also cover the interest charges on the loan taken by the producers to pay the workers. Under these assumptions, we can show easily that the LTV holds, i.e. the price ratio is equal to the ratio of unit labor requirements:

$$
\frac{P_{A}}{P_{B}}=\frac{5 w(1+r)^{2}}{3 w(1+r)^{2}}=\frac{5}{3}
$$

Nevertheless, a minor change in the assumptions of the model can disturb this equality. Simply assume that the wine produced by A matures in three years instead of two but leave everything the same as before. The new price equations are as follows:

$\mathrm{P}_{\mathrm{A}}=5 \mathrm{w}(1+\mathrm{r})^{3}$

$\mathrm{P}_{\mathrm{B}}=3 \mathrm{w}(1+\mathrm{r})^{2}$

$$
\frac{p_{A}}{P_{B}}=\frac{5 w(1+r)^{3}}{3 w(1+r)^{2}}=\frac{5(1+r)}{3}
$$

Hence the price ratio is no longer equal to the ratio of unit labor requirements as before. In other words, the LTV does not hold.

As indicated by Smith's celebrated parable, the LTV holds exactly as a theory of relative prices only in a primitive society where labor is the only scarce factor of production. Ricardo also recognized the shortcomings of the LTV as the basis of a price theory under conditions of modern capitalism, but he considered it a useful approximation anyway.

In contrast, Marx attributed great significance to the LTV for reasons of his own. He argued that a capitalist economy was characterized by a sharp dichotomy. On the surface, one observed prices and profits as the appearance of capitalism. This appearance, however, masked the reality underneath which consisted of values and surplus values. The appearance of prices corresponded to the reality of values and the appearance of profits corresponded to the reality of surplus values. Hence the LTV provided the systematic link between the domains of appearance and reality since labor values underlay prices and surplus values underlay profits. After these preliminary remarks, we are ready to introduce the basic glossary of Marxian economics. 


\section{I.I The basic glossary of Marxian economics}

Note that all variables in Marxian economics are expressed in terms of labor time.

Constant capital (c): Raw materials and fixed capital used in production measured in terms of labor time. To simplify the analysis, we assume that fixed capital does not exist. Constant capital consists exclusively of raw materials that are completely used up and reproduced in one production period.

Variable capital ( $v)$ : The labor time required to produce the wage goods necessary for the workers' subsistence.

Surplus value (s): Given the money wage rate, the length of the working day, skills of the labor force, and the price of the commodity, workers spend only a part of the working day to be able to buy the goods necessary for their subsistence. The rest of the working day, they work for the capitalist. This is the surplus value measured in terms of labor time.

The rate of surplus value: The ratio of surplus value to variable capital, $\sigma=\mathrm{s} / \mathrm{v}$ (the rate of exploitation)

Rate of profit $(s / c+v)$ : the ratio of surplus value to the sum of constant and variable capital, all variables measured in terms of labor time.

Organic compositon of capital $(c / v$ or $c / c+v)$ : The ratio of constant to variable capital. Sometimes Marx used an alternative definition as the ratio of constant to constant plus variable capital. Either defintion can be used as a proxy for the capital-labor ratio. For example, an increase in the organic composition of capital is equivalent to an increase in the capital-labor ratio.

Now we can restate the LTV in Marxian terminology and prove it:

In a two sector economy in long-run stationary equilibrium with a uniform rate of surplus value, a uniform organic composition of capital and a uniform capital good in both sectors, the LTV will hold.

\section{I.2 Definition of variables:}

$\rho_{i}=$ profit rate in department (sector) $\mathrm{i}$

$\mathrm{P}_{\mathrm{i}}=$ price of good $\mathrm{i}$

$\sigma_{i}=$ rate of surplus value (rate of exploitation) in department $\mathrm{i}$

$\mathrm{a}_{\mathrm{i}}=$ unit labor input coefficient in the production of good $\mathrm{i}$

$\mathrm{P}_{\mathrm{k}}=$ price of the uniform capital good (raw materials) which is used in both sectors

$\mathrm{k}_{\mathrm{i}}=$ organic composition of capital in department i, i.e. $\mathrm{k}_{\mathrm{i}}=\mathrm{c}_{\mathrm{i} / \mathrm{v}}$ 
$\mathrm{W}=$ money wage rate

It is important to realize at this juncture that Marx's definition of the profit rate must be reformulated so that it has the same meaning as the standard definition of the profit rate in the Ricardo-Sraffa tradition, i.e. the ratio of money profits to the value of capital invested.

In order to accomplish this reformulation, we need to introduce an assumption which Marx did not use but does not violate his interpretation of capitalist production all the same. We are going to assume that every good is produced by direct labor and that fixed production coefficients are in effect. Note that $s$ is the number of hours that every worker works for the capitalist during the working day. If $a_{i}$ is the unit labor input coefficient in the production of good $i$, we can express profits in physical units as follows:

$$
\mathrm{a}_{\mathrm{i}} \mathrm{q}_{\mathrm{i}}=\mathrm{s}_{\mathrm{i}} \text { and } \mathrm{q}_{\mathrm{i}}=\mathrm{s}_{\mathrm{i}} / \mathrm{a}_{\mathrm{i}}
$$

Similarly, $\mathrm{c}_{\mathrm{i}}$ is the amount of constant capital used in the production of good $\mathrm{i}$ expressed in terms of labor time. Given an index of labor productivity, unit labor input coefficient in the production of the capital good, $\mathrm{a}_{\mathrm{k}}$, we can express the physical quantity of capital used in the production of the $\mathrm{i}$ th good as follows:

$$
\mathrm{a}_{\mathrm{k}} \mathrm{q}_{\mathrm{ki}}=\mathrm{c}_{\mathrm{i}} \text { and } \mathrm{q}_{\mathrm{ki}}=\mathrm{c}_{\mathrm{i}} / \mathrm{a}_{\mathrm{k}}
$$

Since the total number of hours worked by the workers in the production of good $i$ is $s_{i}+v_{i}$, the corresponding money wage bill is $\mathrm{w}\left(\mathrm{s}_{\mathrm{i}}+\mathrm{v}_{\mathrm{i}}\right)$. Now we are ready to express the rate of profit as the ratio of money profits to the value of capital invested:

$$
\rho_{i}=\frac{p_{i}\left(\frac{s_{i}}{a_{i}}\right)}{p_{k}\left(\frac{c_{i}}{a_{k}}\right)+w\left(s_{i}+v_{i}\right)}
$$

where $\rho_{i}$ is the profit rate in the production of good $i$. Dividing the numerator and the denominator of the expression of the profit rate for the first good by $v_{1}$, we have

or

$$
\rho_{1}=\frac{\frac{p_{1\left(\sigma_{1}\right)}}{a_{1}}}{p_{k}\left(\frac{k_{1}}{a_{k}}\right)+w\left(\sigma_{1}+1\right)}
$$

Now we are ready to proceed with the proof of our theorem.

\section{Given:}

$\sigma_{1}=\sigma_{2}$ and $\mathrm{k}_{1=} \mathrm{k}_{2} \quad$ (by assumption.) 
$\rho_{1}=\rho_{2} \quad$ (by the definition of long-run stationary equilibrium)

To Prove: $\quad \mathrm{p}_{1} / \mathrm{p}_{2}=\mathrm{a}_{1} / \mathrm{a}_{2}$

$\frac{p_{1}\left(\frac{\sigma_{1}}{a_{1}}\right)}{p_{k}\left(\frac{k_{1}}{a_{k}}\right)+w\left(\sigma_{1}+1\right)}=\frac{p_{2}\left(\frac{\sigma_{2}}{a_{2}}\right)}{p_{k}\left(\frac{k_{2}}{a_{k}}\right)+w\left(\sigma_{2}+1\right)}$

Profit rates are equalized in long-run stationary equilibrium.

$\mathrm{p}_{\mathrm{k}}\left(\mathrm{k}_{1} / \mathrm{a}_{\mathrm{k}}\right)=\mathrm{p}_{\mathrm{k}}\left(\mathrm{k}_{2} / \mathrm{a}_{\mathrm{k}}\right)$

By the assumption of uniform organic composition of capital and a uniform capital good in the production of both goods.

$\mathrm{W}\left(\sigma_{1}+1\right)=\mathrm{w}\left(\sigma_{2+1}\right)$

By the assumption of a uniform rate of surplus value in both departments.

$\mathrm{P}_{\mathrm{k}}\left(\mathrm{k}_{\mathrm{l}} / \mathrm{a}_{\mathrm{k}}\right)+\mathrm{w}\left(\sigma_{1}+1\right)=\mathrm{P}_{\mathrm{k}}\left(\mathrm{k}_{2} / \mathrm{a}_{\mathrm{k}}\right)+\mathrm{w}\left(\sigma_{2}+1\right)$

which is implied by steps (2) and (3).

$\mathrm{P}_{1}\left(\sigma_{1} / \mathrm{a}_{1}\right)=\mathrm{P}_{2}\left(\sigma_{2} / \mathrm{a}_{2}\right)$

after cancelling out the common denominator in the profit rate expression.

$\mathrm{P}_{1} / \mathrm{a}_{1}=\mathrm{P}_{2} / \mathrm{a}_{2}$ or $\mathrm{P}_{1} / \mathrm{P}_{2}=\mathrm{a}_{1} / \mathrm{a}_{2}$ (Q.E.D.)

since $\sigma_{1}=\sigma_{2}$ by assumption, they can be cancelled out.

It is important to realize at this juncture that while equal profit rates $\left(\rho_{1}=\rho_{2}\right)$ and equal rates of surplus value $\left(\sigma_{1}=\sigma_{2}\right)$ can be rationalized under conditions of LRSE, this is not true for the organic composition of capital, $k_{1}=k_{2}$. In other words, this equality will not hold generally in LRSE except by coincidence. Consequently, the LTV is generally not valid as a theory of relative prices under conditions of modern capitalism where all inputs must be paid positive prices. ${ }^{2}$

It is interesting to note that Marx was aware of these complications, but he did not want to abandon his dichotomic vision of capitalism where prices and profits belonged to

2 It is important to indicate here that when we use Marx's own definition of the profit rate, $s / c+v$, equal profit rates and equal organic compositions of capital in the two departments imply equal rates of surplus value. Hence it may seem a bit peculiar to assume equal rates of surplus value among the 'givens' of our proof. The reason is that, in our reformulation, this will only be true in the trivial case where $\mathrm{a}_{1}=\mathrm{a}_{2}$ and $\mathrm{k}_{1}=\mathrm{k}_{2}$ but not otherwise. The justification of equal rates of surplus value is another thorny issue to which we are not addressing ourselves. As Joan Robinson says, "Marx entangled himself in an artificial difficulty by starting from the assumption of a uniform rate of exploitation. There is no warrant for this assumption." Robinson 1969 [1942], 15. 
the domain of appearances and values and surplus values to the domain of reality. His position can be interpreted as follows: Even though a systematic correspondence cannot be established between relative prices and labor values on a commodity by commodity basis under advanced capitalism, two invariance conditions can be shown to hold in the aggregate (for the economy as a whole), namely the sum of values is equal to the sum of prices and the sum of surplus values is equal to the sum of profits. Marx's inconclusive attempt to demonstrate these invariance conditions gave rise to the famous transformation problem the discussion of which lies beyond the scope of this paper. ${ }^{3}$

It is important to realize that, from a strictly technocratic standpoint, labor is not any different from other factors of production such as capital and land. This is pointed out by Mark Blaug in the following passage:

"Marx merely attributes all income to labor and so presumes the existence of a purely fictitious ratio $\mathrm{s} / \mathrm{v}$, arbitrarily set equal across all industries. If, instead, he had operated with a capital theory of value, attributing the whole of the surplus to machinery and implements, and defined the rate of surplus value as $\mathrm{s} / \mathrm{c}$, he could have carried on transforming values into prices in exactly the same way as he did. It is not always appreciated that the assumption that will make s/v equal between industries, namely an equal organic composition of capital everywhere, will also make $\mathrm{s} / \mathrm{c}$ equal everywhere. With a capital theory of value, we can say that all capitalists share in a pool of surplus value, a pool created solely by the nonhuman factors of production." 4

Blaug is quite correct in arguing that under appropriate assumptions, we can prove the capital theory of value and show that relative prices are equal to the ratio of unit capital requirements, i.e. the amounts of capital (raw materials) required to produce one unit of each commodity. When we reflect on this conclusion for a minute, we should realize that this is a situation that is to be expected under conditions of capitalism. No input will be used in production if the value of output attributable to it cannot pay for the input and does not generate normal profits. Therefore all factors of production are 'exploited' in the same sense labor is. ${ }^{5}$ If they were not, their use in

3 Marx attempted to demonstrate the validity of these invariance conditions by means of a numerical example in the third volume of Capital, (1967), [1894] ,155. Böhm-Bawerk discovered an error in his analysis which he described in Böhm-Bawerk 1949 [1896] . Böhm-Bawerk's critique gave rise to a massive literature on the transformation problem. We will limit ourselves here to citing Bortkiewicz (1907), Winternitz (1948) and Seton (1957) as the most important pioneers who showed formally how values could be transformed into prices and vice versa but also demonstrated that there was no necessity for both invariance conditions to hold simultaneously.

4 Blaug (1997), 225-226.

5 Even though Mark Blaug is well known for his anti-Marxist and pro-neoclassical position, recently a prominent Sraffian radical has made the same point even more empathically:

"In other words, just as values proved to be redundant when explaining capitalist prices, the Marxian rate of exploitation proves to be redundant when explaining capitalist profits. Moreover, we could just as easily define a theory of value based on any basic good in the economy. In fact, one can prove that the rate of profit is positive if and only if every basic input is "exploited" when we choose to define values embodied in terms of that input... Moreover, the fact that capitalists obtain profits based on every input to production, not just the labor they hire, is a fundamental characteristic of capitalism, not some sort of deception we must avoid being tricked by, as Marxists would have us believe. Capitalists achieve positive profits by marking up every input, not just labor. And it is anyone who does not understand this who is deceived, and fails to understand something important about how capitalism 
production would not be justified. Consequently, we cannot claim that value is created by labor alone. A similar claim can be made about each and every factor of production. This analysis needs to be qualified by the observation that even though non-human inputs can be squeezed without limit, there are existential limits to how far labor can be exploited. It would not be rational for the capitalist to pay a wage rate below the level required to ensure the physical survival of workers.

Can we go further, then, and conclude that the capitalist class is fully entitled to appropriate profits? The answer to this question is not so simple. Two issues must be distinguished here. First, the existence of profits in the production process, secondly, the appropriation of these profits by a capitalist class which owns the means of production. Concerning the first issue, we just saw that a valid technocratic argument can be formulated to justify the existence of profits from the viewpoint of allocative efficiency. Moreover, this argument is valid under socialism as well as capitalism. ${ }^{6}$

This brings us to the second issue: Can we justify the appropriation of profits by the capitalist class? The existing property relations in a stylized capitalist economy are such that there is a fundamental asymmetry between the roles assumed by capitalists and workers. Although workers must sell their labor power in order to survive, capitalists are under no obligation to do so. The capitalists' right to appropriate profits arises from a given property distribution prior to the production process which also serves to reinforce that distribution pattern. Therefore in order to find a justification for the appropriation of profits by the capitalist class, we have to find a justification for the private ownership of the means of production. While liberals think such a justification exists, socialists think it does not.

\section{Some Macrodynamic Implications of the Reformulated Profit Rate}

Having investigated the implications of our reformulation for the Marxian theory of value and distribution, it is time now to turn to the Marxian theory of capitalist development. Here we are going to focus on two of Marx's predictions concerning the future of the capitalist economy and try to see if any of these predictions is affected by our reformulation. First, we will consider the law of the falling rate of profit, and, secondly, we will consider the law of the increasing misery of the proletariat.

Using Marx's own terminology, we can demonstrate the law of the falling rate of profit as follows:

$$
\mathrm{r}=\frac{s}{c+v}
$$

works." Hahnel (2017), pp. 29-30.

6 The key reference here is Oskar Lange's economic theory of socialism where he demonstrates without invoking the LTV that efficient resource allocation in a socialist economy can be consistent with marginal cost pricing, assuming certain behavioral guidelines for socialist managers. Lange (1964). 
In accordance with Marx's own assumptions, the organic composition of capital (c/v) rises in the course of capitalist development, the rate of surplus value $(\mathrm{s} / \mathrm{v})$ remaining constant. This leads to a fall in the profit rate.

Unfortunately, the demonstration of the law of increasing misery is not as straightforward because Marx seems to have adhered to different versions of the law at different times. There are essentially three different versions of the law. First, there is the law of increasing absolute misery which predicts that workers will suffer a decline in real wages in the course of capitalist development. Secondly, there is the law of increasing relative misery which predicts that workers'share of national income will decrease over time despite the fact that workers may become absolutely better off. Finally, there is an interpretation of the law which emphasizes the alienation and dehumanization of the working class attributable to capitalist development without any specific reference to changes in real wages.

Marx seems to have abandoned the absolute version of the law in his later writings possibly after observing the gradual rise in the living standards of the English working class during his stay in England. The third version of the law, though important in its own right, is not readily amenable to economic analysis. ${ }^{7}$ Consequently, we will take up the second version of the law and see under which assumptions it can be validated. First, however, we will address ourselves to an important criticism of these two laws first pointed out by Joan Robinson:

"Assuming constant periods of turnover, so that $\mathrm{c}+\mathrm{v}$ measures the stock of capital, when $\mathrm{s} / \mathrm{v}$ is constant and $\mathrm{c} / \mathrm{v}$ is rising, $\mathrm{s} / \mathrm{c}+\mathrm{v}$ is falling, This proposition stands out in startling contradiction to the rest of Marx's argument. For if the rate of exploitation tends to be constant, real wages rise as productivity increases. Labour receives a constant proportion of an increasing total. Marx can only demonstrate a falling tendency in profits by abandoning his argument that wages tend to be constant. This drastic inconsistency, he seems to have overlooked, for when he is discussing the falling tendency of profits he makes no reference to the rising tendency of real wages which it entails" 8

The implication of Robinson's argument is that, in Marx's own terms, there is no necessity for both the law of the falling rate of profit and the law of increasing misery to be valid simultaneously. Additional assumptions have to be introduced to obtain this result.

In our formulation of the profit rate, a rise in the organic composition of capital $\left(\mathrm{k}_{\mathrm{i}}\right)$ will increase labor productivity and result in a decrease in the unit labor input coefficient $\left(\mathrm{a}_{\mathrm{i})}\right.$. Assuming a constant rate of surplus value, workers will be able to produce a higher level of output during the portion of the working day alloted to the capitalist. Profits measured in physical units of output

7 Especially significant in this regard is E.P. Thompson's The Making of the English Working Class which makes a strong case for the alienation and dehumanization of the English working class while steering clear of the long and acrimonious debate between liberal and Marxist economic historians as to whether real wages rose or fell during the industrial revolution. 
will rise. If the product price stays constant, profits measured in value terms will rise as well. To guarantee a falling rate of profit, the rise in the organic composition of capital must more than offset the decrease in the unit labor input coefficient.

To guarantee a simultaneous decrease in the relative share of output going to workers, we have to assume in addition that the rate of surplus value rises in the course of capital accumulation, lowering the relative share of labor in output, increasing profits measured in physical units of output even further. Nevertheless, since $\mathrm{k}_{\mathrm{i}}$ and $\sigma_{\mathrm{i}}$ both appear in the denominator of the expression of the profit rate, it is possible for the profit rate to decrease despite the increase in the rate of surplus value so long as the rise in the organic composition of capital more than offsets the increase in the rate of surplus value. ${ }^{9}$

As far as the historical record is concerned, the 'stylized facts' of economic growth experienced by developed countries in the approximately seventy years before the Second World War were consistent with Harrod-neutral technical change where output per man increased over time, the capital-output ratio and the profit rate remaining constant. This, in turn, implied that the relative shares of capital and labor remained constant as well. ${ }^{\mathbf{1 0}}$ More recently, however, the trend of relative shares has deviated from stylized facts, and there has been a rise in the relative share of capital. ${ }^{11}$ In conclusion, we can say that even though it is logically possible for the law of the falling rate of profit and the weaaker version of the law of increasing misery to hold simultaneously when appropriate additional assumptions are introduced, historical trends have not been categorically in favor of the Marxian laws of capitalist development.

\section{Conclusion}

We can summarize our conclusions as follows:

First, the introduction of a simple production function along with product and factor prices increases the number of necessary conditions which must be satisfied if the LTV is to hold as a proportionality theorem where the ratio of unit labor requirements is equal to the ratio of product prices. Specifically, a uniform rate of surplus value in the two departments must be assumed to guarantee the validity of the LTV in long-run stationary equilibrium in addition to the assumption of a uniform organic composition of capital in the two departments.

Secondly, as far as the Marxian predictions are concerned, the simultaneous validity of the falling rate of profit and the law of increasing relative misery cannot be guaranteed because there is no necessity for the rise in the organic composition of capital to more than offset the decrease in the unit labor input coefficient to ensure a falling rate of profit, and, moreover, there is no necessity

9 For a highly abstract analysis of the conditions necessary for the simultaneous validity of the law of increasing misery and the law of the falling rate of profit, see Steedman (1977), Chapter 9, pp. 116-136.

10 See Kaldor (1957) and Solow (1987)

11 See Kanbur and Stiglitz (2015) for an analysis of these new trends in income distribution. 
for the rate of surplus value to rise in the course of accumulation to ensure the increasing relative misery of the proletariat.

Perhaps it would be appropriate to conclude our analysis with a tribute to Joan Robinson who was one of the first to highlight the analytical flaws in Marx's theory of value and distribution and his theory of capitalist development. My proof of the LTV shows formally why equal rates of surplus value in the two departments is a necessary condition for the validity of this theory, confirming her claim in this regard. Secondly, my introduction of a simple production function to Marxian analysis highlights the conditions that would be necessary to remove the conflict between the falling rate of profit and the increasing misery of the proletariat which was again pointed out by her.

\section{References}

BLAUG, M. (1997) [1962] , Economic Theory in Retrospect, Cambridge: Cambridge University Press BORTKIEWICZ, August Von, (1949) [1907] "On the Correction of Marx's Fundamental Theoretical Construction in the Third Volume of Capital", Böhm-Bawerk 1949, 197-221.

BÖHM-BAWERK, Eugen von, (1949) [1896] Karl Marx and the Close of His System, New York: Augustus M. Kelley

HAHNEL, Robin, (2017), Radical Political Economy: Sraffa versus Marx, London and New York: Routledge, Taylor Francis Group

KALDOR, Nicholas (1957), "A Model of Economic Growth", The Economic Journal, (67) (268): 591-624

KANBUR, Ravi and STIGLITZ, Joseph, (2015), "Wealth and Income Distribution: New Theories Needed for a New Era”, VOX, CEPR's Policy Portal

LANGE, Oskar, (1964) On the Economic Theory of Socialism New York: McGraw-Hill

MARX, Karl, (1967) [1894] , Capital: A Critique of Political Economy (three volumes), New York: International Publishers

ROBINSON, Joan, (1969) [1942], An Essay on Marxian Economics, London: Macmillan

SETON,F., (1957), "The Transformation Problem", Review of Economic Studies, 24, 149-160.

SMITH, Adam, (1937) [1776] An Inquiry into the Nature and Causes of the Wealth of Nations, New York: The Modern Library

SOLOW, Robert, (1987) [1970] , Growth Theory: An Exposition, New York, Oxford University Press

STEEDMAN, Ian, (1977), Marx after Sraffa, London, New Left Review Editions

THOMPSON, E.P. (1966) [1963], The Making of the English Working Class, Vintage Books, 1966

WINTERNITZ, J. (1948), "Values and Prices: A Solution of the So-Called Transformation Problem", Economic Journal, 58, 276-280. 